\title{
HEALTH PROPERTIES OF SELECTED HERBAL PLANTS
}

\section{WŁAŚCIWOŚCI PROZDROWOTNE WYBRANYCH ROŚLIN ZIELARSKICH}

\author{
$\operatorname{Marta~Kozak}^{1(\mathrm{~B}, \mathrm{E})}$, Paweł Sobczak ${ }^{1(\mathrm{D})}$, Wioletta Żukiewicz-Sobczak ${ }^{2(\mathrm{~A}, \mathrm{~F})}$ \\ ${ }^{1}$ Department of Food Engineering and Machines, Faculty of Production Engineering, \\ University of Life Sciences in Lublin, Poland \\ ${ }^{2}$ Pope John Paul II State School of Higher Education in Biała Podlaska, Institute of Health Sciences, \\ Department of Public Health, Regional Research Center of Environment, \\ Agriculture and Innovative Technologies EKO-AGRO-TECH, Poland
}

Authors' contribution Wkład autorów: A. Study design/planning zaplanowanie badań B. Data collection/entry zebranie danych C. Data analysis/statistics dane - analiza i statystyki D. Data interpretation interpretacja danych E. Preparation of manuscript przygotowanie artykułu F. Literature analysis/search wyszukiwanie i analiza literatury G. Funds collection zebranie funduszy

Tables: 0

Figures: 0

References: 29

Submitted: 01.12.2015

Accepted: 11.02.2016

\begin{abstract}
Summary
Herbs contain many biologically active natural substances and their properties have made it possible for people to use herbs in cooking and medicine for centuries. The use of herbal mixtures can prevent the illnesses, regenerate the body, regulate intestinal flora, strengthen the nervous, respiratory, digestive and circulatory systems. The objective of the study is the presentation of selected species of medicinal plants which are important to human body.

Valuable, healthy properties of herbs result from the contained within them biologically active compounds such as glycosides, flavonoids, alkaloids, essential oils, tannins, bitterness, locks, pectin, minerals and vitamins. Properly matched herbs are natural and safe agents for treatment of many illnesses. Herbal preparations are prepared from fresh or dried, suitably comminuted plants and can be used internally and externally. They help to maintain good health and generally strengthen the body. Herbs are not only used in herbal medicine, but also in the food, cosmetic and perfumery industries.

Herbal medicine is an effective method to take care of health by preventing illnesses and their treatment. Herbs have antibacterial properties, reduce the risk of cardio-vascular diseases and cancer, they can reduce the level of cholesterol in the blood and provide support to the respiratory and digestive systems. The proper selection of herbs and method of they consume is critical, because some of them have toxic properties, and various kinds of illnesses or specified physiological states constitute contraindications to their use.
\end{abstract}

Keywords: Melissa officinalis, Matricaria chamomilla, Salvia officinalis, Thymus vulgaris, herbal medicine

\section{Streszczenie}

Zioła zawieraja wiele naturalnych substancji biologicznie aktywnych i ze względu na swoje właściwości są od wieków wykorzystywane w kuchni i lecznictwie. Stosowanie ziołowych mieszanek może zapobiegać wystąpieniu chorób, regenerować organizm, regulować florę bakteryjną jelit, wzmacniać układ nerwowy, oddechowy, trawienny oraz krążenia. Celem pracy jest przedstawienie wybranych gatunków roślin zielarskich ważnych dla organizmu człowieka ze względu na ich właściwości lecznicze.

Cenne właściwości prozdrowotne ziół wynikają z zawartych w nich związków biologicznie aktywnych takich jak: glikozydy, flawonoidy, alkaloidy, olejki eteryczne, garbniki, gorycze, śluzy, pektyny, składniki mineralne i witaminy. Właściwie dobrane zioła są naturalnymi i bezpiecznymi środkami w leczeniu wielu chorób. Ziołowe preparaty wytwarzane są ze świeżych lub suszonych, odpowiednio rozdrobnionych roślin i mogą być stosowane zarówno wewnętrznie jak i zewnętrznie. Pomagają utrzymać dobry stan zdrowia i ogólnie wzmacniają organizm. Wykorzystywane są nie tylko w ziołolecznictwie, ale również w przemyśle spożywczym, kosmetycznym i perfumeryjnym.

Ziołolecznictwo stanowi skuteczną metodę dbania o zdrowie poprzez zapobieganie chorobom, a także ich leczenie. Zioła posiadają działanie antybakteryjne, zmniejszają ryzyko wystąpienia chorób układu sercowo-naczyniowego i nowotworów, mogą obniżać poziom cholesterolu we krwi oraz wspomagać pracę układu oddechowego i trawienia. Ważny jest właściwy dobór ziół oraz sposób ich spożywania, ponieważ niektóre z nich posiadają toksyczne właściwości, a różnego rodzaju choroby lub określone stany fizjologiczne stanowią przeciwwskazania do ich zażywania.

Słowa kluczowe: Melissa officinalis, Matricaria chamomilla, Salvia officinalis, Thymus vulgaris, ziołolecznictwo 


\section{Introduction}

Herbs have been used since time immemorial both for curative and culinary purposes. Due to their unique taste, aroma and preservative features herbs are used as measures of prolonging the durability of food and for seasoning of various dishes. They are also a component of food products belonging to the group of functional foods, which positively affect the human body, improve health and reduce the risk of some diseases $[1,2,3,4]$. Herbal plants are commonly used in the pharmaceutical, perfume and cosmetic industry. They are successfully used in skin and hair care as well as in animal nutrition improving their health, productivity and beneficially influencing the products obtained from them. They are applied in the form of food additives, preparations or herbal extracts. Herbal raw materials are obtained from their natural state and field crops [2,5].

In recent years, both in Poland as well as in the world, interest in herbal medicine has continued to grow. It is a result of a rapid development of diseases such as cancer, neuroses and allergies, which until recently were considered as incurable. Properly selected herbs bring relief during these diseases and lead to their inhibition or even extinction. The use of herbal blends helps to regenerate the human body, regulate the intestinal flora, purify the blood and all endocrine glands, strengthen the nervous and digestive system. The therapeutic value of herbs is in place due to the presence of specific biologically active substances in them, which are characterized by different chemical compositions and they are located in varying amounts in different parts of plants. Sometimes, herbal plants may exhibit toxic properties, and the difference between therapeutic dose might be very similar to the toxic one. For this reason, the use of herbs requires both expertise and caution. There are also various types of contraindications to the use of herbs, especially in the case of certain illnesses, or even certain physiological conditions. Moreover, it should be remembered that, at the end of the herbal treatment one needs to pause slightly before starting the second one, since consumption of herbs in excess can adversely affect the body $[2,5,6,7]$.

\section{Aim of the work}

In the following work selected herbal plants such as melissa (Melissa officinalis), wild camomile (Matricaria chamomilla), sage (Salvia officinalis) and thyme (Thymus vulgaris) have been discussed, which are commonly used because of their health-promoting properties. It also provides basic information on herbs and the active substances contained within them.

\section{Brief description of the state of knowledge}

The active compounds present in the herbal plants are the product of two types of plant metabolism. The first group contains basic substances, the so-called basic metabolic products such as carbohydrates, fats, proteins, amino acids, enzymes, etc. The second group includes the products of nitrogen metabolism, which may be divided into the following categories: essential oils, glycosides, flavonoids, alkaloids, tannins, bitter substances, saponins, coumarins, locks, pectin, minerals and vitamins [3]. These compounds indicate a high physiological activity, which is dependent on the chemical composition of a given substance, the dose and the method of its use [8].

The essential oils are mixtures of volatile compounds and they are characterized by strong odor and insolubility. Mostly, they are colorless, however they may occur in yellowish, greenish or blue colour. Chemically, they are heterogeneous, and each oil contains dozens of components, where one or two are considered as dominant, and suitable properties of the whole oil. The essential oils have a number of properties, for instance, an antibacterial, anti-inflammatory, disinfectant effect, as well as they may act stimulating or calming, being expectorant, diuretic, cholagogue, able to support digestion, as well as improve the taste of dishes [9,10].

Glycosides are a combination of simple sugars with the non-sugar compounds by the glycosidic bond. The most common are cardiac glycosides, which improve the work of heart and reduce the frequency of heartbeats. Phenolic glycosides may act diuretically and as anti-inflammatory agents, anthocyanin ones strengthen capillary blood vessels, mustard disinfects and improve blood circulation, and anthraglycosides are used in gastrointestinal disorders [11,12].

Flavonoids are colored compounds, soluble in water, present in the plant cells, protecting them against the harmful effects of UV radiation and pests. The main groups of flavonoids are the flavones- yellow colorings and anthocyanins adopting different color depending on the acidity of the environment (from the color of the orange-red through purple to violet). Flavonoid compounds have the ability to quench free radicals that show the following properties: anti-inflammatory, antioxidant, antispasmodic, diuretic, anti-atherosclerotic, having a calming effect on the central nervous system, acting as phytoestrogens, reducing arterial pressure, facilitating 
the absorption of vitamin $\mathrm{C}$ and removing from the body ions of heavy metals [11,13].

Alkaloids are a group of diverse heterocyclic compounds containing nitrogen in its ring and strongly affecting the human and animal body. Alkaloids administered in low doses are an effective medication for numerous diseases and ailments, e.g. atropine is a medication used to stimulate the central nervous system, reduce the spams of gastrointestinal tract, expand pupils; quinine is used to treat fevers and treat malaria, codeine acts antitussive, caffeine stimulates blood circulation and reduces drowsiness and morphine has a desensitizing and anesthetic action [8,14]. In case of an overdose they are likely to cause food poisoning. Among the alkaloids, there are also some poisonous substances and many of them are components of drugs, such as cocaine or nicotine.

Tannins are polyphenolic and nitrogen-free substances which are classified due to the chemical structure as hydrolyzing, condensed and non-hydrolyzing compounds. Tannins have strong astringent and bactericidal properties, inhibit digestion and absorption processes, stop bleeding, act antidiarrheally, antidotally and antiseptically $[11,12]$.

Bitters are natural and bitter substances, which irritate the taste buds, stir the appetite and enhance the work of the digestive system. These compounds also have antispasmodic, astringent and anti-inflammatory properties [2]. Saponins on the other hand are glycosidic compounds, which have the ability to lower surface tension of liquids and to make them lather. These compounds increase the secretion of the mucus and ease its excretion from respiratory tracks, preventing accumulation of cholesterol and facilitating digestion [8].

Coumarin are a group of heterocyclic aromatic compounds, having diastolic, anticoagulant, antipyretic, sedative and diuretic properties [12]. Whilst polysaccharides and proteins are contained in the mucus. It has protective and coating properties for gastrointestinal tract, facilitate digestion, prevent constipation, support the treatment of ulcer diseases and act antitussive $[8,11]$.

Pectins (polysaccharides) are not digestible by enzymes of the gastrointestinal tract. They reduce the cholesterol and support the treatment of diarrhea. Moreover, they protect the gastrointestinal tract, binding water and metal ions, giving the sensation of its fullness, so they can be used in obesity treatment and fat metabolism disorders [12].

Due to the fact that, the active substance content is irregular in plants, herbal raw material constitutes the part which contains the greatest proportion of these substances. Any part of the plant rich in active compounds is another raw herbal material, which means that, several kinds of raw materials can be obtained from the same plant, collected in different ways and at a different time $[3,15]$. The freshly picked herbs should be stored in plastic containers, at temperatures between +2 and $-18^{\circ} \mathrm{C}$, and those well dried herbs, shall be stored in sealed paper/linen containers or in glass containers, which are kept away from light, in the well-ventilated place. Herbs, during drying and storage, gradually lose their medicinal value, since active substances contained in herbs, undergo thermal decomposition [7].

Herbal products are made from fresh or dried plants, which are properly crumbled and used singly or in mixtures. Herbal medications can be designed for internal and external use. The extracts are the primary type of herbal preparations for internal use. These herbs are obtained by etching plant material by specified solvent, and then by obtaining proper thickness of preparation. Depending on the level of thickness liquid extracts (Extracta fluida), thick extracts (Extracta spissa) and dry extracts (Extracta sicca) are distinguished. Tablets, granulates and capsules are produced directly from dry extracts, and dense extracts represent an intermediate in the preparation thereof. Liquid extracts are divided due to the solvent used for their preparation and thus, water extracts, alcohol extracts or extracts prepared from the mixtures of both substances are distinguished. Water extracts are prepared from raw or dried herbs, by infusing crushed material with water for a short period of time. Because of their short shelf life it is best to use them immediately. The method of preparing this kind of extracts depends on the properties of biologically active substances of a plant. Depending on the method of preparing an extract, we distinguish between infusions, decoctions and macerates. Stabilized alcohol extracts, also known as Alcoholaturae or Intracta, are prepared from raw herbal material with ethanol as the solvent. Tinctures are made from dried plant material in a similar method that one in Alcoholaturae. They constitute a concentrated, liquid form of herbal medicine. Infusions and tinctures are the most commonly used herbal medicinal products. There are many ways in which herbs may be used externally. The most common ones are: compresses, ointments and creams $[4,16,17]$.

\section{Lemon balm (Melissa officinalis)}

Lemon balm is a is a perennial plant in the mint family (Lamiaceae), native to the Mediterranean region. It has a distinctive stem, branching, square and grey, slightly hairy. The leaves are dark grey, pleated-serrated and with petiolated, heart-shaped form. Lemon balm grows up to $80 \mathrm{~cm}$ and has a strong, citronella odor. It blooms from 
June to September and its flowers are small and two-lipped, whitish or pinkish, sitting in the axils of upper leaves where they form top inflorescences. Its fruit is a dark brown schizocarp, its root system is well-developed [3,18,19]. This herb is widely grown as a medicinal and melliferous plant. Raw or dried leaves and young stems of lemon balm are a valuable spice that can be used in soups, sauces, salads, meat and fish. They are also used for flavouring teas, liqueurs and fruit cocktails $[3,18]$. The essential oil of a strong, citronella scent is a valuable material in perfume and cosmetics industries and as a food preservative $[9,20]$. The leaves are the herbal material the most important ingredient of which is the essential oil containing terpenes, e.g. citral, caryophyllene, linalool and citronellal. The other active substances in lemon balm leaves are: tanins, bitter substances, phenolic acids (caffeic, rosmarinic and ferulic acid), triterpenes, flavonoids, organic acids, mucus, resin, minerals and vitamin C [2,16,21].

Lemon balm has the following properties: sedative, strengthening, carminative, diuretic, diaphoretic, antispasmodic, antibacterial, antiviral and anti-inflammatory. It also regulates liver metabolism and lowers blood pressure. Lemon balm may also inhibit the growth of some cancer cells. It is used to relieve the symptoms of bowel cancers. In modern herbalism, lemon balm is used in states of irritability and anxiety, as a sedative and in curing migraines, insomnia and cardiac neuroses. Lemon balm helps digest food better and is used in various digestive disorders, alimentary tract and bile ducts cramps. The studies have shown that regular consumption of lemon balm infusions by people suffering from Alzheimer's disease positively influences their cognitive functions and relieves the symptoms of senile dementia. What is more, lemon balm may lower the level of cholesterol in blood and therefore prevent atherosclerosis [22,23].

Lemon balm is also used externally as a soothing and healing agent against wounds, ulcers, burns and as an ingredient of mouthwashes in the case of gum inflammation. It may also be used to rinse hair in conditions of seborrhoea and scalp inflammation. It was proven that the tannins and phenolic acid present in the water extracts from lemon balm control the virus of labiate herpes (Herpes simplex). Lemon balm leaves are a component of many herbal mixtures, ointments, alcohol extracts and sedative pills [17,24].

Substances containing lemon balm may enhance the effects of other herbs and drugs with sedative properties or those decreasing the enzymatic production of the thyroid. Consuming lemon balm in too large doses may lead to drowsiness and allergic reaction. Due to the possibility of allergies, kids under the age of eight, pregnant and breastfeeding women should consume lemon balm with caution. People suffering from glaucoma should avoid the essential oil from lemon balm, because the studies report that it may raise the intraocular pressure [9].

\section{German chamomile (Matricaria chamomilla)}

German chamomile, also known as common chamomile, can be found throughout the whole Europe, Asia, North America and Australia. It belongs to the composite family (Asteraceae) and is an annual plant, growing to $60 \mathrm{~cm}$, with a delicate, branching stem. The leaves are green, bipinnate or tripinnate, deeply incised, linear and slightly twirled. Single inflorescences in forms of heads grow at the ends of the shoot tips. They consist of inner and outer flowers, blooming from May to autumn. Margin white ray florets lean down as they wither. Middle yellow disc florets are embedded in a convex bottom of the flower head $[18,19,25]$. Flower heads are a valuable herbal material, they contain up to $1.5 \%$ essential oil rich in substances with therapeutic effects, such as: chamazulene, $\alpha$-bisabolol and its oxides, farnesene, myrcene, cadinene. Chamomile flowers also contain flavonoids, coumarins, mucus compounds, choline, spiroeter, mineral salts and vitamin C $[15,16]$.

Chamomile can be used to treat a number of medical conditions. It displays disinfectant, anti-allergic, antispasmodic, sedative and laxative effects and can be used to treat ulcers. Thanks to its properties, it is recommended in anxiety-related stomach aches. Chamomile is used in preventing and treating breast, ovarian and prostate cancer. Its anti-carcinogenic properties result from the presence of flavonoids that inhibit the diffusion of cancer cells. What is more, chamomile is used to relieve the symptoms of stomach, bowel and liver cancers. It can be used as infusions, alcohol extracts and as an ingredient of various herbal mixtures. Chamomile tea is particularly recommended for infants with stomach aches. Chamomile is also an ingredient of mouthwashes used in all kinds of inflammations [15,25]. Methods of external use of chamomile include inhalations, baths and ointments with antibacterial properties, with the ability to bind bacterial toxins and stimulate wound healing [9]. Compresses soaked in chamomile infusion are used in treating skin inflammations, burns and eye, conjunctiva and eyelid inflammations [26]. Essential oil from chamomile is used in treating varices, pimples or mucous membranes irritation. Furthermore, it is used in eczemas, urticarias or in cases of dry, itching and flaking skin. Oil rubbed in scalp stops the hair from falling out. Chamomile has brightening properties and that is why it is a valuable material in cosmetic industry in the production of shampoos and conditioners for light hair, skincare creams and many other cosmetics $[9,10]$.

Active substances in chamomile flowers may cause severe allergic reactions. Because of this, people with 
recognised hypersensitivity or allergy to plants from composite family (Asteraceae) should be extra careful while using products containing chamomile, as they may trigger a cross-allergy reaction. It should be noted that consuming chamomile infusions for a long period of time may lead to contact eczema and disrupted menstruation $[25,26]$.

\section{Common sage (Salvia officinalis)}

Common sage is a perennial, evergreen subshrub, native to Mediterranean region, belonging to the mint family (Lamiaceae). It is an entomophilous and melliferous plant, growing up to $40-60 \mathrm{~cm}$. Its stems are branched, grey-green, woody from the bottom and slightly hairy. The leaves are lanceolate, with long stalks and serrated margins and have veining forming a tiny net, slightly convex from the bottom. Sage blooms in June and July, its flowers are light purple or pink, gathered on stem tops in inflorescences in forms of spikes. The whole plant emits a distinctive, strong, camphorous fragrance $[3,18,19]$. The herbal material of sage are its leaves, containing about $2.5 \%$ of essential oil and being rich in bitter substances, tanins, saponins, triterpenes, flavonoids, organic acids, carotenoids, resins, mineral salts and vitamins B1, C, PP. The main ingredients of sage oil are thujone, eucalyptol, camphor, borneol and pinene. The oil is used in treating colds, sinus infections, wet cough, respiratory diseases and bad breath. It reduces swellings after injuries and insect bites. It is used in aromatherapy and in perfume industry as a fragrance preservative. It is also an ingredient of many herbal toothpastes $[2,9,10]$.

Common sage has an anti-inflammatory, antiseptic, antibacterial and anti-fungal properties. It was proven to inactivate bacterial toxins and inhibits the growth of bacteria resistant to antibiotics. Common sage can be used in treating digestive diseases with excessive fermentation in bowels, because it relaxes smooth bowel muscles spasms and restores their proper functioning. Sage relieves stomach aches, stimulates digestion and food absorption, relieves nausea and prevents diarrhoeas. It supports liver treatment in case of toxin-induced damage and compromised biliary secretion and reduces inflammations of mucous membranes, mouth, palate and gums [2,3]. Sage infusion is used in cases of kidney and urinary tract failures and is added to baths relieving skin and rheumatic ailments or used as compresses against slow-healing wounds or varicose veins-related leg ulcerations. It has been reported that using sage in leukemia treatment has a positive effect [18]. Decoctions from its leaves are used in case of diabetes, because it lowers sugar level in blood and it prevents excessive perspiration when added to the bath. Sage roots are used in the production of infusions with an estrogenic effect and supporting the treatment of coronary heart diseases, arterial hypertension and cardiac neuroses [19].

Sage is an ingredient of herbal shampoos and conditioners, due to its anti-dandruff and anti-inflammatory effect on scalp and because it strengthens and naturally darkens the hair and prevents hair loss [3]. It is not only a herb of many medical properties, but also an exquisite spice used as a seasoning for meat, because it stimulates digestion and has flavouring properties [7,18].

Thujone, present in the essential oil, has neurotoxic properties and that is why consuming large doses of common sage or consuming it for a long period of time may lead to muscle tremor, seizures, dementia, headaches and dizziness, hallucinations, even the loss of consciousness and miscarriages. The symptoms of thujone poisoning include stomach aches, nausea, vomiting, diarrhoea and increased heart rate. Sometimes a rash, red spots or urticarias occur $[16,19,26]$.

\section{German thyme (Thymus vulgaris)}

German thyme, commonly known as thyme, belongs to the mint family (Lamiaceae) and grows up to 30-40 $\mathrm{cm}$. It is native to Mediterranean region and is also cultivated in many countries in both Americas and in Europe, including Poland. Its stems are distinctively branched and woody from the bottom. The leaves are tiny, green and linear-lanceolate but grey and hairy from the bottom side. German thyme blooms from June till July, its flowers are tiny and lilac, gathered on stem tops in inflorescences in forms of heads. Its fruit is a small, round achene, dark black-brownish in colour $[3,18]$. When harvested at the right time and dried properly, thyme should maintain its natural green-grey colour, intensive and bitter scent and burning taste. German thyme is a valuable harvested herbal material, its most important ingredient is the essential oil rich in thymol, cymen, linalool and carvacrol. Moreover, German thyme contains flavonoids, tanins, bitter substances, saponins, vitamins B and C, sugars and mineral salts $[2,3]$.

Thyme is used as a expectorant in cases of cough and bronchial secretion and in asthma. In air passages it kills bacteria which are often resistant to antibiotics, that is why it is used in cases of hoarseness, inflammation of the larynx, dry and persistent cough [26,27]. Bitter substances in German thyme stimulate gastric acid secretion and by doing so, positively influence digestion. German thyme stimulates appetite, prevents poisonings and 
relieves their symptoms, prevents the excessive fermentation in the digestive tract, reduces bloating and stomach-cramps and kills bowel parasites. What is more, thyme also prevents stomach and colorectal cancers and squamous cell mouth carcinoma. Thyme strengthens the nervous system, stimulates the blood flow, helps fight drowsiness and enables people to work intellectually without getting tired. It is sometimes used externally, as an ingredient of mouthwashes in inflammations and sore throat or larynx. Compresses from thyme infusions are applied to swellings, bumps and bruises. Decoctions, on the other hand, are used to rinse cuts and ulcers. Thyme baths have disinfectant, strengthening, analgesic, anti-inflammatory and stimulating effects, that is why they are recommended in cases of skin inflammation, infections, seborrhoea or acne. Infusions from thyme are used in treating hair loss and dandruff. German thyme is also an ingredient of herbal hair conditioners that restore the healthy look of hair $[2,15]$.

Essential oil prepared from thyme in the process of steam distillation is also used in herbalism. Thanks to its antibacterial properties, it is used topically in cases of abscesses and mycoses and as inhalations in sore throat or larynx. Thyme oil has its use in dentistry in sterilization of surgical tools. It is also used as an insecticide. Thymol, isolated from the essential oil, after being diluted with water is recommended as a mouthwash to stimulate healing of small wounds and to rinse root canals after dental treatment, due to its astringent and analgesic properties $[27,28]$. Thanks to its antiseptic and preservative properties, it is used in the production of canned food, perfume products, syrups, decoctions and extracts. Thyme oil is an ingredient in the production of liqueurs or herbal wines and also in cosmetic industry in the production of toothpastes or mouthwashes. In a household, thyme oil is used for disinfecting and providing fragrance in the air $[9,10,28]$.

Thymol, present in the essential oil, may have a strong toxic effect and should be therefore used with extra caution. Thyme oil should always be diluted before applying it directly on skin and should not be consumed, because of a possibility of seizures, coma, sudden cardiac arrest or breathing difficulties. Using thyme oil for a long period of time may result in headaches, general sense of weakness or even in kidney irritation $[16,19]$. German thyme should not be consumed by people with recognized allergies or hypersensitivity to thyme or other plants from the mint family (Lamiaceae), as it may trigger allergy reactions, including skin reactions and swellings and digestive ailments. People suffering from diabetes or hypoglycemia should consume thyme with caution, because it lowers blood pressure [29].

German thyme is not only a medical plant, but also a spice that enriches the taste of many dishes, most distinctive of French cuisine. Raw or dried green parts of cultivated and wild species are used $[1,18]$.

\section{Conclusions}

Herbal preparations are absorbed better by the human body than synthetic drugs, they are less aggressive and have an diverse impact on human body. Beside active substances, they also provide many valuable vitamins, biocatalysts, enzymes, macro- and microelements. Preparations from raw or dried herb, such as infusions, decoctions, tinctures or extracts, play an important role, just like herbs used in treating heart diseases, cardiovascular, digestive and nervous problems. Thanks to its anti-inflammatory, antibacterial and anti-fungal properties they are used in treating conditions in which antibiotics fail to work. Herbal medicine may lower the risk of having cancer, lower the level of cholesterol in blood and stimulate respiratory health. It can be also used externally, as compresses in case of slow-healing wounds. When using herbal medicine, we should remember about the right choice of herbs and the way in which they are supposed to be consumed, because some of them may have a toxic effect on our bodies and certain diseases or physiological conditions may constitute a contraindication for their consumption. Herbs are a valuable material in cosmetic industry, used e.g. in the production of toothpastes, creams, shampoos and hair conditioners. Some herbal materials slow down fats oxidation and inhibit the growth of microorganisms and because of that they are used as natural preservatives in food industry. What is more, herbs are also widely used in households, e.g. to repel insects, disinfect and refresh the air and as cleaning products.

\section{References:}

1. Borowy T, Kubiak M. Przyprawy ziołowe - subtelność smaku. GM. 2009; 4: 18-20 (in Polish).

2. Fijałkowski D, Chojnacka-Fijałkowska E. Rośliny lecznicze na Lubelszczyźnie. Lubelskie Towarzystwo Naukowe, Lublin 2009 (in Polish).

3. Senderski M. Zioła. Praktyczny Poradnik o Ziołach i Ziołolecznictwie. Warszawa: Wydawnictwo K.E.; 2009 (in Polish).

4. Peter KV. Handbook of herbs and spices. Volume 1. Woodhead Publishing Series in Food Science, Technolog, 
Witney 2001.

5. Tapsell LC, Hemphill I, Cobiac L, Sullivan DR, French M, Patch CS i wsp. Health benefits of herbs and spices: the past, the present, the future. Med J Australia. 2006; 185(4): 1-24.

6. Craig W. Health - promoting properties of common herbs. Am J Clin Nutr. 1999; 70(3): 491-499.

7. Wrzodak A, Wrzodak R. Właściwości prozdrowotne i sposoby przechowywania świeżych ziół. Hasło Ogrod. 2008; 10: 117-119.

8. Senderski M. Zioła w leczeniu dolegliwości serca i chorób układu krążenia. Podkowa Leśna: Wydawnictwo Herbavis; 2011 (in Polish).

9. Góra J, Lis A. Najcenniejsze olejki eteryczne. Toruń: Wydawnictwo Uniwersytetu Mikołaja Kopernika; 2005 (in Polish).

10. Kalemba D, Kunicka A. Antibacterial and antifungal properties of essential oils. Curr Med Chem. 2003; 10: 813-829.

11. Kudełka W, Kosowska A. Składniki przypraw i ziół przyprawowych determinujące ich funkcjonalne właściwości oraz ich rola w żywieniu człowieka i zapobieganiu chorobom. Zesz Nauk. 2008; 781: 83-111 (in Polish).

12. Skarżyński A. Zioła czynią cuda. Warszawa: Agencja Wydawnicza Comes; 2008 (in Polish).

13. Majewska M, Czeczot H. Flawonoidy w profilaktyce i terapii. Ter Leki. 2009; 65(5): 369-377.

14. Kapusta F. Zioła i ich znaczenie dla człowieka. Pr Nauk Uniw Ekon Wroc. 2007; 1172: 7-19.

15. Kemper FH. The Scientific Foundation for Herbal Medicinal Products. European Scientific Cooperative on Phytotherapy, United Kingdom 2003.

16. Farmakopea - Polska Wyd. IX, T. 2. Urząd Rejestracji Produktów Leczniczych, Wyrobów Medycznych i Produktów Biobójczych. Warszawa: Polskie Towarzystwo Farmaceutyczne; 2011 (in Polish).

17. Janicki S, Fiebig A. Farmacja stosowana. Podręcznik dla studentów farmacji. Warszawa: Wydawnictwo Lekarskie PZWL; 1998 (in Polish).

18. Falandysz G. Bogactwo natury - zioła. Barzkowice: Zachodniopomorski Ośrodek Doradztwa Rolniczego; 2009 (in Polish).

19. Kuźniewski E, Augustyn-Puziewicz J. Przyroda Apteką. Jak rozpoznać i stosować zioła. Wrocław: Wydawnictwo Dolnośląskie; 2006 (in Polish).

20. Bagdad RB, Cosge B. The Essentials oil of lemon balm (Melisa officinalis L.), its components and using fields. J Fac Agr. 2006; 21(1): 116-121.

21. Nurzyńska-Wierdak R. Melisa lekarska (Melissa officinalis L.) - skład chemiczny i aktywność biologiczna. Ann UMCS Sect DDD. 2013; 23 (1): 25-35.

22. Dastmalchi K, Ollilainen V, Lackman P, Boije af Gennäs G, Dorman HJ, Järvinen PP, Yli-Kauhaluoma J, Hiltunen R. Acetylcholinesterase inhibitory guided fractionation of Melissa officinalis L. Bioorg Med Chem 2009; 17(2): 867-871.

23. Obulesu M, Rao DM. Effect of plant extracts on Alzheimer's disease: An insight into therapeutic avenues. J Neurosci Rural Pract. 2011; 2(1): 56-61.

24. Moradkhani H, Sargsyan E, Bibak H, Naseri B, Sadat-Hosseini M, Fayazi-Barjin A i wsp. Melissa officinalis L., a valuable medicine plant: A review. J Med Plants Res. 2010; 4(24): 2753-2759.

25. Lewkowicz-Mosiej T. Zioła naszych Kresów. Praktyczny poradnik wykorzystania leczniczych mocy roślin. Białystok: Studio Astropsychologii; 2003 (in Polish).

26. Strzelecka H, Kowalski J. Encyklopedia zielarstwa i ziołolecznictwa. Warszawa: Wydawnictwo Naukowe; 2000 (in Polish).

27. Sienkiewicz M, Wasiela M. Aktywność olejków tymiankowego i lawendowego wobec opornych na antybiotyki szczepów klinicznych Pseudomonas aeruginosa. Post Fitoter. 2012; 3: 193-145.

28. Lis A. Olejki tymiankowe. Aromater. 2003; 3: 5-13.

29. Szumny D, Szypuła E, Szydłowski M, Chlebda E, Skrzypiec-Spring M, Szumny A. Leki roślinne stosowane w chorobach układu oddechowego. Dent Med Probl. 2007; 4(44): 507-515. 